\title{
Vankina kaivoksen talouskirouksessa
}

\section{Maarit Laihonen, KTT, tutkija, Aalto-yliopiston kauppakorkeakoulu}

Juha Kauppinen \& Sampsa Oinaala: Talvivaaran vangit. Siltala 2016. Marko Erola: Kirottu kaivos. Totuuden jäljillä Talvivaarassa. Talentum 2014.

Talvivaaran kaivos, joka nykyisin on Terrafame-nimisen valtion kaivosyhtiön omistuksessa (jatkossa yksinkertaisuuden vuoksi käytän vain Talvivaara -nimeä), on Suomessa eittämättä viime vuosien seuratuin yksittäinen teollisuusprojekti, joka erityisesti kasvavien ympäristöongelmien takia on saanut laajaa huomiota. Talvivaara on inspiroinut jopa kolmea elokuvaprojektia: Talvivaaran miehet -dokumentissa (2015) tarkasteltiin konkurssin partaalla horjuvaa kaivosta sen työntekijöiden silmin; puolifiktiivisessä jännitysdraamassa Jättiläinen (2016) rakennettiin trilleri kovan teollisuuspolitiikan keskellä kamppailevan virkamiehen näkökulmasta; ja Nälkämaan Sampo -dokumentissa (2016) erityisesti kansalaisten ympäristöstä huolestunut ääni pääsi esiin.

Tarkastelen tässä Talvivaaran tarinaa kahden hyvin erilaisen kirjan kautta. Painotan Talvivaaran vankeja syystä, jonka tarkennan myöhemmin, mutta analysoin koko kuvaa myös Kirotun kaivoksen kautta. Erilaisuudestaan huolimatta kirjojen tarinat kietoutuvat yhteen kaivoksen kohtalon kannalta keskeiseksi muodostuneen talouskysymyksen kautta. Näillä journalistisilla kirjoilla onkin erityinen anti myös tutkijoille juuri siinä, että ne avaavat yhden merkittävän tapauksen, jossa itse (kaivos)liiketoiminnalla oli hyvin vähän tai ei juuri mitään tekemistä tiettyjen toimijoiden saavuttaman taloudellisen edun kanssa.

Talvivaaran vangit kertoo Talvivaaran tarinan kokonaisuudessaan pieninä tarinoina eri näkökulmista kaivoksen alkuajoista saakka. Kirjan esseemäinen muoto tekee esityksestä poukkoilevaa, koska Kauppinen ja Oinaala kirjoittavat omilla tyyleillään vuorotellen. Varsinkin alkuosassa poukkoilua tulee myös siitä, että kirjoittajat käyvät välillä läpi omaa suhdettaan (ja rooliaan) poliittiseksi kuumaksi perunaksi muodostuneessa tarinassa. 
Kirja kertoo pieniä tarinoita ja tuo esiin erilaisia näkökulmia ja valtavan paljon yksityiskohtia, mutta tarjoaa keskittyvälle lukijalle myös kokonaiskuvaa vuosien tapahtumista. On lähiympäristön asukkaiden, laajemman toiveikkaan Kainuun, virkamiesten, poliitikkojen, aktivistien, työntekijöiden, ja lopulta Pekka Perän ja muiden avainhenkilöiden tarinoita. Kirja paranee loppua kohti kertomusten osalta. Kirjan perusteella Talvivaaran ympäristössä eletään koko ajan surullisessa toivossa, joka kuitenkin liukenee kiihtyvällä vauhdilla nopeammin kuin nikkeli Talvivaarassa. Lisäksi kirjassa käydään läpi Talvivaaran teknologiaan (bioliuotus) liittyviä ongelmia ja ympäristöongelmia vuosien varrelta.

Kirottu kaivos -kirjan kuvauksessa kerrotaan teoksessa olevan kyseen kirjasta "joka haastaa käsityksen siitä, mikä Talvivaarassa lopulta meni pieleen ja millä seurauksin. Syntyi kertomus siitä, miten pieni suuren menetyksen ja suuren menestyksen ero voi olla. [...]”. Itse asiassa kirjassa ei pystytä täsmällisesti osoittamaan, mikä meni pieleen, vaan siinä osoitellaan sormella yhtä lailla virkamiehiä, poliitikkoja, mediaa, aktivisteja sekä lopulta vetäytyneitä suursijoittajia ja analyysikyvyttömiä "kaikenmaailman dosentteja". Kirjassa kyllä todetaan kattavasti lukuisat talousongelmat, mutta ne ovat aina muiden kuin itse yhtiön vika. Teknisiä ongelmia ei myönnetä, vaan bioliuotukseen uskotaan loppuun saakka, vaikka julkaisupäivään mennessä näyttöjä teknologian toimimisesta ei ollut - eikä toistaiseksi ole - kaivoksen vaatimassa mittakaavassa. Erola ohittaa mitättömin huomautuksin yhtiön sisäiset ongelmat, joista toimittajan kuvittelisi nimenomaan kiinnostuvan. Toisaalta Erola kuvailee kirjoittaneensa kirjan paitsi toimittajana myös Talvivaaran osakkeenomistajana.

Erola heittelee erilaisia numeroita väitteidensä tueksi: on sivukaupalla lukuja päästöistä, malmimääristä ynnä muusta. Lukijan on kuitenkin mahdotonta seurata, mitkä luvut liittyvät toisiinsa, kun ne esiintyvät saman asian yhteydessä mutta kymmenien sivujen päästä toisistaan. Lukujen esittäminen ja vertailu on tärkeää, kun puhutaan kriittisistä talouskysymyksistä. On kuitenkin aivan eri asia esittää niitä luettavasti ja vertailtavasti tai ilmaan heitellen. Yli kolmensadan sivun kirjassa tällä alkaa jo olla merkitystä, koska lukijan on mahdotonta pitää kirjaa vertailuluvuista kymmenien sivujen välillä. Kun kirjoittaja haluaa kritisoida muiden esittämiä lukuja, olisi loogista pyrkiä itse ainakin systemaattiseen esitykseen. Esimerkistä käy kirjoittajan kritiikki median esittämiä päästömittaustuloksia kohtaan ympäristölupien sisältämiin lukuihin nähden. 
Näiden ongelmien lisäksi Erola käyttää lukuisia sivuja syytelläkseen erilaisia tahoja Talvivaaran kohtaamista ongelmista, mutta samalla kuvailee syyttämiään ja kohtaamiaan ihmisiä varsin erikoisella tavalla ottaen huomioon, että hän haluaa tehdä syvällistä talousjournalistista kirjallisuutta. Kirjassa vilisevät niin nälkiintyneen oloiset hipit kuin asiallisen oloiset naiset, joiden kuvailun merkitys Talvivaaran surullisen tarinan suhteen jää epäselväksi.

Kauppinen ja Oinaala onnistuvat kaikessa siinä, missä Erola epäonnistuu, mikäli kirjoja tarkastelee katsauksina Talvivaaran lyhyeen historiaan. Talvivaaran vangit esittelee erilaisia näkökulmia ja kirjoittajat tarkastelevat myös omaa toimintaansa kriittisesti. Kirottu kaivos sen sijaan väittää avaavansa totuuden verhon, vaikka kirja paljastuu tyyliltään tuskalliseksi pettyneen sijoittajan itkuvirreksi ja pyrkimykseksi Pekka Perän henkilökultin ylläpitämiseksi. Talvivaaran vangit tarjoaa mielenkiintoisia näkökulmia niillekin, jotka eivät ole niin kutsutun kriittisen talousjournalismin ensisijaista yleisöä, kun taas Kirottu kaivos on avoimesti yhden henkilön ristiretki niitä vastaan, jotka ovat syystä tai toisesta koskaan sanoneet poikkinaista sanaa kirjoittajan ihannoimasta projektista.

Kirjoittajina Kauppinen, Oinaala ja Erola ovat hyvin erilaisia. Kauppinen tunnetaan asiakirjapohjaisista reportaaseistaan, Oinaala syvällepureutuvista kertomuksista, joissa hän pureutuu pieneenkin tarinaan syvälle. Kauppinen ei esimerkiksi Talvivaaran vangit -kirjassa esitä olevansa niin sanottu ympäristöihminen. Tämä käy ilmi, kun lukee hänen tekstejään kirjassa tai alkuperäisissä Talvivaara-artikkeleissa, vaikka hänen tekstinsä olivatkin keskeisessä osassa nostamassa Talvivaaran ympäristöongelmia laajaan tietoisuuteen. Oinaala on erikoistunut syrjäseutuja käsittelevään kirjoittamiseen ja hänen juttujaan löytyy samoin useista medioista. Sijoitustoiminnasta, pokerista ja taidekaupasta aiemmin kirjoittaneelle Erolalle Talvivaara sen sijaan on Kirottu kaivos -kirjan tyylin perusteella henkilökohtaisempi kysymys.

Molempien kirjojen kiinnostavin anti on se, miten kaivoksen loputon taloudellinen alamäki kuvataan molemmissa kirjoissa. Kauppinen ja Oinaala eivät kerro tarinaa nimenomaan taloustarinana, mutta heidän esittämistään lukuisista tarinoista kuroutuu yhteen monikerroksinen tarina, jossa yhdistyvät yrittäjäsankaritarinan toivo, rakennemuutoksen lyömä Kainuu ja sen toivo pysyvistä työpaikoista sekä lukuisat tarinat suuremmista ja pienemmistä osakkeenomistajista ja paikallisten käymistä korvaustaistoista. Erolan alkuperäisenä 
tarkoituksena oli näyttää kuinka negatiivinen mediahuomio tuhosi kaivoksen talouden. Hän itse listaa kaivoksen tekniseen ja taloudelliseen osaamiseen liittyvät ongelmat, mutta päätyy syyttämään niistä kaikkia muita paitsi yrityksen teknisistä ja talousasioista vastanneita henkilöitä.

Kirjoista piirtyy kaksi varsin erilaista ison kuvan kertomusta: on Talvivaaran taloudellinen kertomus, jossa avainhenkilöt tekivät isot omaisuudet ja lukuisat muut hävisivät, sekä tekninen tarina, jossa lainoin ja osakeannein kerätyllä rahalla ei näytä olevan mitään tekemistä itse nikkelintuotannon kanssa. Kaivoksen rikastuttamat ihmiset eivät kirjojen perusteella missään vaiheessa rikastuneet kaivoksella, vaan siitä kerrotulla tarinalla. Lopulta itse tarinakin kaatui ja kaivos sen mukana valtionyhtiö Terrafamen, eli käytännössä veronmaksajien, syliin.

Talvivaara elää edelleen toiveiden varassa. Vielä toukokuussa 2017 saatiin kuulla, kuinka tuotannon odotetaan olevan kannattavaa loppuvuodesta 2018. Edellisellä kerralla lupailtiin saman vuoden alkua. Talvivaara on traaginen esimerkki niistä yrittäjyyssankaritarinoista, joiden pitäisi nostaa kituva isänmaa uuteen nousuun. Nykyisin näitä tarinoita saa kuulla lähinnä niin kutsuttujen aineettomien innovaatioiden alalla, mutta se ne näyttävät esiintyvän myös maankuoren tarjoamasta vauraudesta riippuvaisilla aloilla. Tähän markkinarakoon Talvivaaran oli tarkoitus iskeä uudella teknologialla, jolla köyhiäkin malmivaroja voidaan hyödyntää maailmanmarkkinahintojen noustessa.

Talvivaaraa on kutsuttu oman alansa "start-upiksi" ja sellainen se tavallaan olikin - ja ainakin toistaiseksi on myös sitä siinä mielessä, että useat niistä kohtaavat konkurssin. Startupien konkursseista seuraa tavanomaisesti eri tahoilta sijoitettujen varojen menetystä, yrittäjän henkilökohtaista kriisiä ja muutamien muiden henkilöiden joutumista takaisin työmarkkinoille. Yleisessä yrittäjyystarinassa konkurssia ei kuitenkaan pidetä katastrofina, vaan uudelleen yrittäjiä ja varsinkin siinä onnistujia ihaillaan ja luodaan uusia tarinoita pohjalta pinnistävistä kaiken menettäneistä sankareista.

Kaikilla tarinoilla ei kuitenkaan ole niin massiivisia materiaalisia vaikutuksia kuin Talvivaaralla on tarinansa varrella ollut - ja tulee vielä pitkään olemaan. Ensinnä tulevat Talvivaaran aiheuttamat ympäristötuhot, jotka molempien kirjojen perusteella johtuvat usein kaivoksen talouden takia tehdyistä laiminlyönneistä. Kauppisen ja Oinaalan tarinassa puhutaan laiminlyönneistä ja välinpitämättömyydestä (esimerkiksi ympäristöjohtajaa ei kuultu, kun hän 
ensi kerran huolestui päästökysymyksistä), kun taas Erola sijoittaja-kirjoittajana vaatii, ettei kaivokselle olisi pitänyt olla niin ankara virkamiesten ja median taholta. Yhtä kaikki, talous asetettiin ilmiselvien ympäristövahinkojen estämisen edelle. Vain tulevaisuus näyttää olivatko nuo säästöt kokonaiskuvassa minkään arvoisia ja paljonko tuhotun luonnon ennallistamisesta vielä maksetaan.

Kaiken tämän keskellä eli ja elää pohjoisen toive työpaikoista - aivan kuten kaikissa muissakin suuren mittaluokan teollisuusprojekteissa. Kauppinen ja Oinaala onnistuvat kuvaamaan sitä ristiriitaa, epävarmuutta ja pelokasta toiveikkuutta, jota tilanne Talvivaaran työntekijöissä aiheuttaa. Ulkopuolella valtio on valmis investoimaan loputtomasti lisärahaa säilyttääkseen kohtuuttoman kalliit työpaikat, jotka Talvivaaran projekti ennen 2010-luvun alkua lupasi. Tarinan yksi opetus onkin, että mikään ei ole Suomessa ja suomalaiselle niin arvokasta kuin työ: se tuo henkilökohtaista merkityksen tunnetta, ja samalla valtion silmissä jokainen tarinoilla luvattu työpaikka on paitsi tuottamattomien taloudellisten investointien myös ympäristöllisten menetysten arvoinen. 